\title{
STATE REGULATION OF THE EDUCATION SECTOR UNDER THE CONDITIONS OF DECENTRALIZATION
}

\author{
Viktor Oharenko', Iuliana Kozachenko²
}

\begin{abstract}
The purpose of the paper is to define general trends and approaches to educational reform under the conditions of decentralization in Ukraine. Methodology. The survey is based on the analysis of the development of the regulatory framework of Ukraine for reforming the education sector under the conditions of decentralization. Statistical data on the dynamics of change in the total number of education institutions are studied. The reasons for the decrease in the total number of secondary and vocational education institutions have been identified. The degree of financing of the education sector from the consolidated budget of Ukraine by levels of education is considered. Results. The article outlines general trends and approaches to educational reform under the conditions of decentralization in Ukraine. The problems of the decentralization process, which began in 2014, were emphasized, namely the regional development and unification of territorial communities, which influenced the dynamics of education institutions that gained more autonomy. The dynamics of the total number of education institutions subordinated to the Ministry of Education and Science of Ukraine in terms of educational levels is presented. It is determined that the education sector in Ukraine is in transition, and an important component of this process is the correct choice of the vector of movement, taking into account the interests of all stakeholders. It is determined that the decentralization reform affects mechanisms of management in education. It is established that decentralization for higher education institutions should be considered as a means of forming managerial relations in the industry and joint responsibility for the management of the educational process. The experience of Great Britain and the European Union (Denmark, Spain, Poland, Romania, Finland, France) on improving the quality of educational services by strengthening the motivation of teachers using a differentiated payment system is studied and proposed to introduce into the Ukrainian education system. Practical implications. The possibility of introducing the process of educational / school clustering is considered. It is established that the introduction of decentralization opens the way to changes in creating favorable conditions for the emergence and implementation of intellectual needs of the individual. It is proved that the main task of the government in education in the conditions of decentralization is to coordinate the actions of government agencies, education institutions and the public in order to meet the personal needs of citizens and government demands for intellectual and professional enrichment. Value/originality. In the course of the research perspectives for development of education in Ukraine at the level of territorial communities, the process of formation of new opportunities in education for users of educational services is formed.
\end{abstract}

Key words: state regulation, education, decentralization in education, educational subventions, management of education.

JEL Classification: A20, H52, H75, 128

\section{Introduction}

The implementation of the decentralization reform in the education sector is aimed at radical changes in the system of management and financing of the sector through district and regional education authorities. The key step to educational reform in the implementation of decentralization reform is the disappearance of the educational "vertical structure", namely the regional departments of education and

\footnotetext{
Corresponding author:

${ }^{1}$ Classic Private University, Ukraine.

E-mail: kpuinform@gmail.com

${ }^{2}$ State Fiscal Service in Zaporizhzhia region, Ukraine.

E-mail:kyup75@ukr.net
}

science, which receive requests and tasks from the branch Ministry and transfer them to the district (city) education department. The decentralization process for implementation of the regional development measures and unification of territorial communities, which has begun in 2014, has also affected education institutions, which have gained greater autonomy, and at the same time, this process has expanded the powers of the local level. Educational reform, first of all, is the issue of 
management of the education system, clear division of powers and responsibilities of governing bodies of different levels, ensuring their interaction in the process of transition to decentralized management of education. The implementation of innovations and best practices in education is the main driving force of change and the key to the development of institutions of different levels of education. Improving the educational space, first of all, involves democratization and consistent implementation of educational reform, so the approach to the implementation of educational reform is a major factor, which requires further study.

The most relevant scientific publications on educational reform in Ukraine, in our opinion, are a number of theoretical and analytical works on the issue of decentralization in education of such recognized scientists and practitioners as: L. Hrynevych, D. Dzvinchuk, H. Yelnikova, V. Luhovyi, N. Protasova, S. Krysiuk, etc. Scientific works highlight the impact on education of the process of decentralization of power and the formation of amalgamated territorial communities. Regarding the problems of reforming the education sector in the process of decentralization of power, the works of such scientists as L. Bielov, I. Popov and O. Yukhou, N. Tarasenko, L. Yurchuk, etc. are relevant. We should also pay attention to the work of such scientists as E. Barsikovskyi, K. Bjork, J. Wood, K. Dyer, P. Rose, D. Chapman, etc. Problems of modernization of the educational process are noted in the scientific works of V. Kremen, L. Kalinina, O. Onats, V. Oliinyk, S. Sysoieva, O. Savchenko, O. Pometun, $\mathrm{O}$. Topuzova, etc. Innovative processes in the search for the relationship between centralized and decentralized management of the system of education institutions are highlighted by the works of such scientists as M. Zghurovsky, P. Hobzei, T. Krystopchuk. Therefore, in our opinion, in the presented scientific publication it is worth highlighting the general trends and approaches to educational reform in a decentralized environment.

\section{The current state of education under the conditions of decentralization}

Since 2014, there have been changes in local self-government, a reform of decentralization of management is being implemented, accompanied by the formation of a viable primary institution of local self-government - a territorial community - through its amalgamation (amalgamated territorial community). From now on, the bodies of village, settlement, city councils are endowed with their own (self-governing) and delegated powers in the education sector:

- management of education institutions owned by territorial communities or transferred to them, organization of their logistical and financial support; - ensuring the acquisition of full general secondary education, creating the necessary conditions for the upbringing of children, youth, development of their abilities, labor training, vocational guidance, productive work of students, promoting the activities of preschool and out-of-school education institutions;

- ensuring that education should be available and free in the relevant territory within the given powers;

- ensuring the development of all types of education, improvement of the network of education institutions of all forms of ownership in accordance with the law (Art. 32 of the Law of Ukraine "On Local SelfGovernment in Ukraine", 1997).

One of the important stages of reforming education under the conditions of decentralization was the introduction of the New Ukrainian School in September 2018. The concept of the "New Ukrainian School" is revealed on the basis of a formula that includes the following: a new content of education, based on the formation of competencies necessary for successful self-realization in society; a motivated teacher who has freedom of creativity and develops professionally; a cross-cutting process of education that shapes values; decentralization and effective management, which will give the school real autonomy; pedagogy based on partnership between student, teacher and parents; focus on the needs of the student in the educational process, child-centeredness; a new school structure that allows to master the new content and gain competence for life; fair distribution of public funds, which ensures equal access of all children to quality education; modern educational environment that will provide the necessary conditions, tools and technologies for teaching students, educators, parents not only in the premises of the education institution (Ministry of Education and Science of Ukraine, 2018).

It should be emphasized that solving the problems of the New Ukrainian School affects the development of preschool education, vocational (technical) education, out-of-school education, training and reskilling of teachers in higher pedagogical education institutions. The main vectors of educational reform under the conditions of decentralization should include: the creation of an effective network of education institutions, based on territorial characteristics, demography, ensuring the quality of education, the competitive influence of other countries, etc.

Figure 1 shows the dynamic pattern in the number of institutions in terms of levels of education, which indicates the relative overall sustainability of the network of education institutions. However, there are some deviations, in particular with regard to preschool institutions; there is a trend of gradual growth since 2015 (by 484 institutions in 2017/2018 compared to the $2015 / 2016$ school year).

However, the number of secondary education institutions is gradually decreasing (by 1428 units in $2017 / 2018$ compared to the $2014 / 2015$ academic year, i.e., by $8.8 \%)$, such a decrease has also affected 
Vol. 6, No. 3, 2020

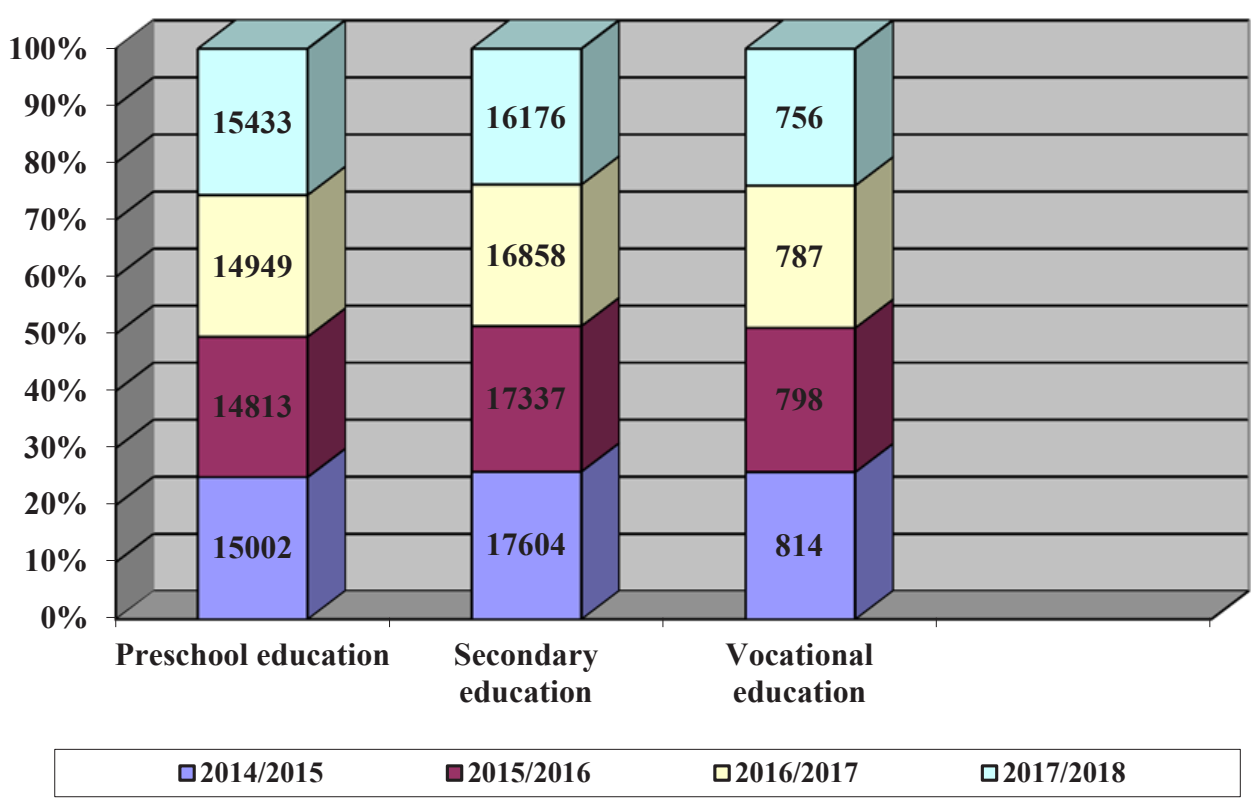

Figure 1. Dynamic pattern in the total number of education institutions subordinated to the Ministry of Education and Science of Ukraine in terms of levels of education (2014/2015-2017/2018), (Education in Ukraine: Basic Indicators, 2018)

vocational education (from the 2014/2015 academic year, their number has decreased by 58 units, which amounts to $7.7 \%$ ). Such trends are explained by the insufficient completeness of secondary and vocational education institutions due to the demographic and migration crisis.

However, according to the legislation of Ukraine, the state is obliged to provide general allocations on education in the amount of not less than $7 \%$ of GDP from the state, local budgets and other sources of financing not prohibited by law. Figure 2 shows the expenditures of the consolidated budget of Ukraine by levels of education in 2014-2018, in \% of the expenditures of the consolidated budget of Ukraine on education.

There is a tendency to reduce the share of consolidated budget expenditures of Ukraine on education relative to GDP (from $7.4 \%$ in 2010 to 5.4\% in 2016). However, already from 2017 to 2018 , there is a significant increase in expenditures on education, for example, in 2018, the volume of expenditures has been $5.9 \%$ of GDP and $16.6 \%$ of the total consolidated budget of Ukraine in 2018.

A study of foreign experience shows that much more money is allocated on education. For example,

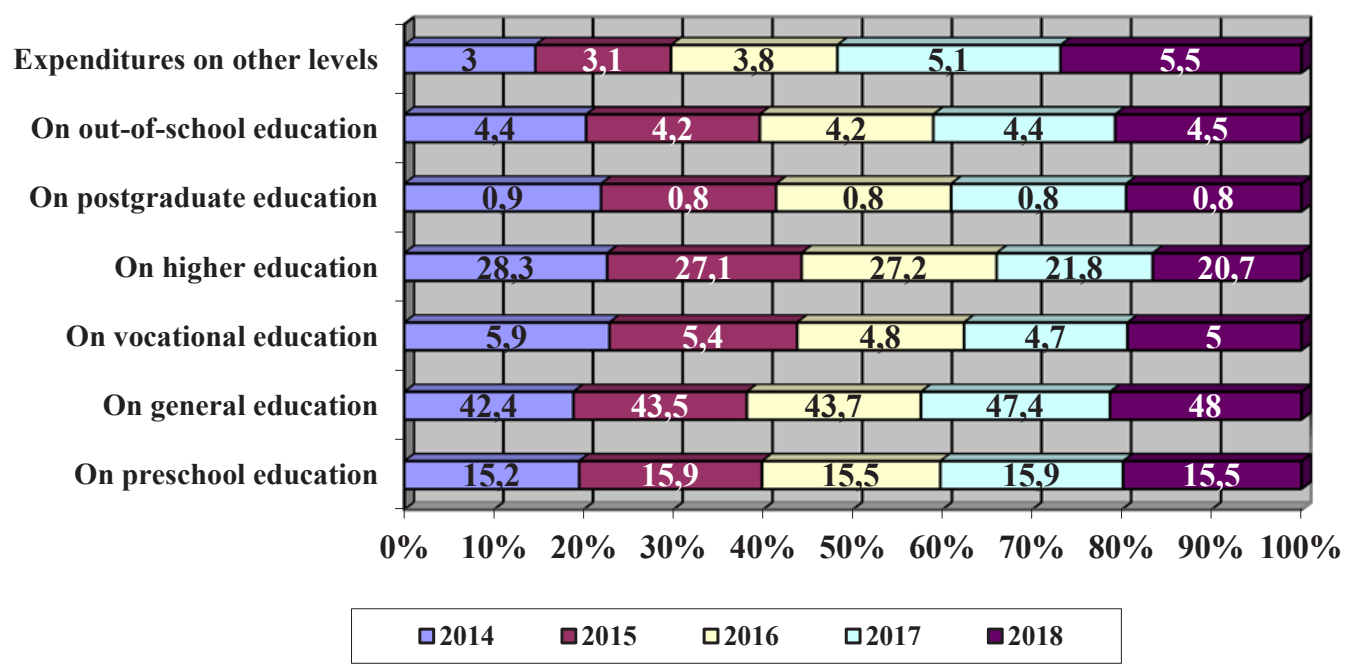

Figure 2. Expenditures of the consolidated budget of Ukraine by levels of education in 2014-2018, $\%$ of expenditures of the consolidated budget of Ukraine on education (Education in Ukraine: Basic Indicators, 2018) 
in Germany, in 2016, expenditures on education has accounted for $23.43 \%$ of total expenditures, and there is an increase (by 1.47 more than in 2014). A significant amount of funds is allocated to finance education in Greece (18.72\% in 2016), in Mexico (17.94\% in 2016) (Table 1).

Table 1

Expenditures on education in \% to total government expenditure

\begin{tabular}{|l|c|c|c|c|}
\hline \multicolumn{1}{|c|}{ State } & 2014 & 2015 & 2016 & $\begin{array}{c}\text { Changes } \\
(2016-2014)\end{array}$ \\
\hline Australia & 13.88 & 14.08 & 13.77 & -0.11 \\
\hline Austria & 10.41 & 10.69 & 10.95 & 0.54 \\
\hline China & 13.39 & 13.37 & 13.52 & 0.13 \\
\hline Germany & 21.96 & 24.09 & 23.43 & 1.47 \\
\hline Greece & 18.74 & 17.80 & 18.72 & -0.02 \\
\hline Italy & 13.97 & 14.13 & 12.89 & -1.08 \\
\hline Mexico & 18.81 & 19.02 & 17.94 & -0.87 \\
\hline The Netherlands & 12.15 & 12.21 & 12.81 & 0.66 \\
\hline Norway & 17.04 & 15.73 & 15.97 & -1.07 \\
\hline Sweden & 15.33 & 15.50 & 15.73 & 0.4 \\
\hline Switzerland & 15.46 & 15.53 & 15.51 & 0.05 \\
\hline $\begin{array}{l}\text { The United } \\
\text { Kingdom }\end{array}$ & 13.67 & 13.84 & 13.83 & 0.16 \\
\hline
\end{tabular}

Source: Expenditure on education as \% of total government expenditure (all sectors), 2020

Today, the education center is in transition, an important component of this process is the right vector to move forward, taking into account the interests of all stakeholders. One of the main challenges of educational reform is the situation in secondary school, which has such features as: overload of students at all stages of learning, outdated content of curricula and textbooks, disinterest of recipients of educational services in the end. Profiling in secondary school (teaching in the so-called specialized classes) does not give students a thorough knowledge, practical skills and, most importantly, it does not force them to look for additional, effective, interesting and necessary classes outside the education institutions. According to the Law "On Education", it is envisaged to obtain specialized secondary education in two areas:

- academic, as a specialized education based on a combination of educational content, defined by the State Standard of Specialized Secondary Education, together with a combination of in-depth study of certain subjects taking into account the abilities and educational needs of students with a focus on continuing education at its higher levels;

- vocational, as market-oriented vocational education based on a combination of educational content, defined by the State Standard of Specialized Secondary Education, and professionally-oriented approach to learning, taking into account the abilities and needs of students (Seitosmanov, Fasolia, Marchlewski, 2019).
Decentralization reform affects management mechanisms in the education sector that provide services to the population, regardless of their affiliation to the place of residence or other characteristics. It should be noted that in centralized management systems, all subsystems of the object of management are carried out by a specific body or managed from one central office. Decentralized systems have the following feature: each subsystem is managed by a separate management body, which is responsible for the results of the subsystem. Decentralized management in general secondary education provides an opportunity to involve various stakeholders (parents, school board members, teachers, the public, employers, other representatives) in the process of planning, organizing and implementing decisions, planned actions, to assess the results of their implementation.

Characteristic features in education are:

- in the management process, the goals of education customers, students and the goals of the system must coincide, i.e., they should not contradict each other;

- in the management of an education institution, the distribution of functions performed in both decentralized and centralized forms must be clearly agreed;

- in the decentralized management of a basic education institution, this process is carried out at two levels: internal and external (Meleshko, 2018).

It is established that decentralization for higher education institutions should be considered as a means of forming managerial relations in the industry and joint responsibility for the management of the educational process. Decentralization for HEI is a new challenge facing the institutions, academic teaching staff. However, it is worth noting that while innovative changes will build partnerships in the education services market, there will be reductions and destructive potential in some aspects, such as reductions in education sector. Therefore, it is necessary to understand at what points the higher education in Ukraine is the most conservative (Tupchak, 2017).

\section{Improving the state policy to support the development of education sector at the level of territorial communities}

In the current context of educational reform, it is advisable to pay attention to the process of implementing education in the form of educational / school clustering (clustering of schools), which is seen as a strategy to pool limited resources and improve access to them. The term "school/educational cluster" means the grouping of neighboring schools to form a cluster or network. Clustering is as follows: one school in a cluster is the main (basic) education institution, or a "core", "center of clusters", central "institution". The mechanisms of administrative management are as 
follows: clusters are responsible for collecting school statistics, allocating school materials, coordinating staff and curriculum issues.

The political aspect of the clustering of education is the involvement of teachers, parents, communities of educators and students in the educational process. The economic aspect is that the school clusters are formed so that schools can share resources and staff. Resource sharing is one of the goals of school clustering (so-called "fair allocation of resources"). The main aspect of clustering is the quality of education, which is improved through the professional growth of teachers, curriculum development, pedagogical supervision and support. E. Giordano identifies four models of school clusters: the national model of clusters; group of educators (teachers, school principals); network; rural clusters (Semeniuk, Kolisnychenko, 2019).

A study of foreign experience shows that such experience is used, but it has certain features. Thus, in Finland, there are currently 162 joint medical centers to serve a number of small municipalities, and specialized medicine covers medical districts under the management of joint municipal councils. Cooperation is carried out in the sectors of education, recycling of waste, water supply, etc. The main models of intermunicipal cooperation are the "model of the manager municipality", when one municipality performs a number of functions for a group of municipalities or a contractual cooperation on utilities and education (Danylyshyn, Pylypiv, 2016).

The implementation of decentralization opens the way to changes in creating favorable conditions for the emergence and implementation of intellectual needs of the individual. The main task of the government in education under the conditions of decentralization is to coordinate the actions of government agencies, education institutions and the public in order to meet the personal needs of citizens and government demands for intellectual and professional enrichment (Boiko, 2017).

It is worth understanding that the division of powers in education is aimed at financial, legal and logistical aspects, as well as responsibility for the content of education and control over the implementation of plans. Statistics and information are obtained from the regions, but are not properly processed and taken into account when making administrative and political decisions. Strategic plans and regional development programs, other state documents and decisions are not formed in clear tasks to heads and management of education at the city, district level, therefore, fulfillment of tasks of educational policy is not provided: there are not developed means, resources from which the expected results can be obtained (Yurchuk, 2009).

Effective implementation of decentralization is the basis for improving the quality of the educational outcomes and education in general. Careful design of the system is needed to reduce the possible negative effects of decentralization, such as regional imbalances, controversial policies and priorities of the elite. Having analyzed the reforms in the management of the education sector in a number of countries, L. Hrynevych formulates a list of the main tasks of decentralization, which are based on: political motives (in most countries, they are the basis for enthusiasm for increasing public participation in government decisionmaking); financial motives (central governments are unable to provide full financing that meets the requirements of education); motives for efficiency (due to the fact that decision-making at the local level helps to reduce the cost of achieving each individual result) (Hrynevych, 2005).

Figure 3 shows new opportunities for the development of education at the level of territorial communities, which is defined as the main vectors of education development in the conditions of decentralization of power, its key areas are: obtaining greater powers by district, city councils and councils of amalgamated territorial communities, educational opportunities, critical aspects of decentralization in education, school / educational clusters, possible options for financing education, change in approaches in public administration.

Possible financing options include: the possibility of receiving a scholarship from the school or the state, receiving grants from local authorities, partial financing from the state budget, prospects for financial assistance, intergovernmental transfers from budgets at all levels.

The study of foreign experience of decentralization of development of education in the direction of changing the financing system has revealed positive trends in the decentralization process. For example, in Poland, thresholds have been set for the education subvention granted to local budgets, the content of which has been to prohibit the allocation of the educational subvention for the next year in a smaller amount than in the previous year (taking into account the inflation rate). At the same time, the share of gminas' own funds that did not come from the educational subvention gradually increased in the financing of education. Despite this allocation, school financing remained stable. Powiats spend about as much of their own money on education as they receive on the educational subvention. In addition to stable financing for current school expenditures, the Ministry of National Education has managed to mobilize additional budget funds for bodies of local self-government on education, depending on needs. This applies to various targeted grant programs: funds for school buses, for partial financing of investments related to the introduction of a new school system, for computer classroom equipment or for annual enrollment of first-graders. The Polish education system has a two-tier financing mechanism. The bodies of local self-government receive an educational subvention, and 


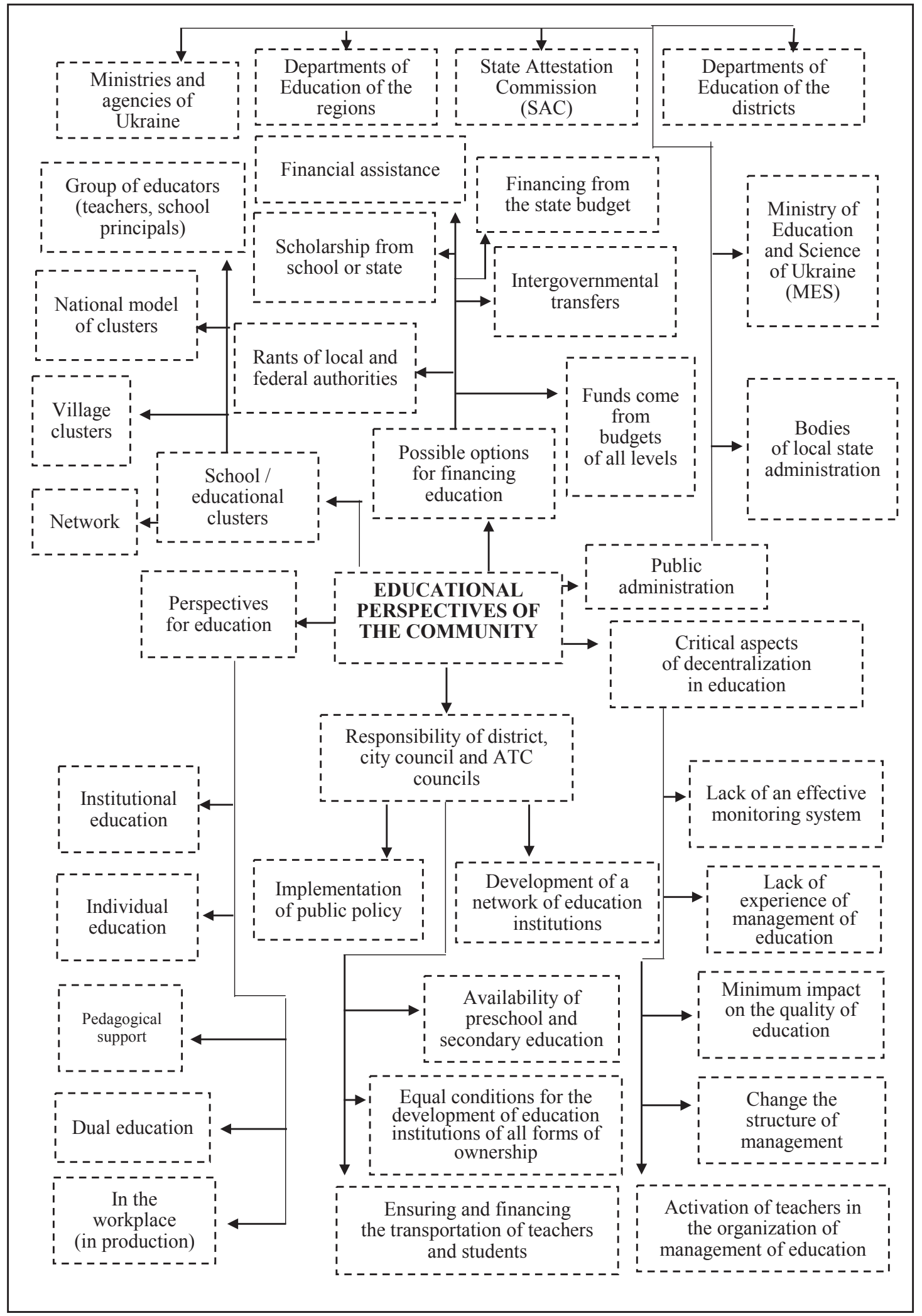

Figure 3. Perspectives of the development of the sphere of education at the level of territorial communities

Source: made by the authors 
then set the budgets of individual institutions and are fully responsible for the financing (Shyian, 2016).

In the United Kingdom, it is recognized that the main incentives to improve education in the conditions of financial decentralization are the market and competition. The government's policy on this issue is that education institutions should: be funded by the state under contracts for educational activities and educational services; depend less on public financing and rely more on a variety of sources of income. In addition, to improve the quality of education, the government of the state has proposed a more thorough evaluation of teachers' work, to introduce differentiated remuneration for this work (teachers' work should be paid depending on the number of students and the level of education); allow the establishment of differentiated tuition fees depending not only on the status of the education institution, but also on the subjects studied (Babichev, 2017).

However, with regard to the expediency of encouraging the work of teachers (by providing allowances), this mechanism is also used in the other European countries. Thus, almost half of the countries pay allowances related to the geographical location of the school. They are motivational incentives that encourage teachers to work in remote, rural or socially disadvantaged areas and are determined at the central level of government. Also, teachers may be paid allowances for work in regions with aboveaverage living standards, such as in the capital. The criteria for such allowances vary considerably from country to country. They can be geographical in nature (remote and isolated areas), which occurs in Denmark, Spain, Cyprus, Poland, Romania, Finland and the United Kingdom (Scotland). On the other hand, they can be economic (high standard of living), as in France and the United Kingdom (England), or social (areas with significant social exclusion, high risk or a large proportion of students representing ethnic or linguistic minorities) as in Spain, France and Italy (Krystopchuk, 2016). This experience should be applied in Ukraine in order to increase the motivation of young professionals to get a job in schools located in rural areas.

It should be understood that changes due to the implementation of decentralization reform will affect the distribution of powers in financial, resource and administrative terms between all levels of control of the education system of Ukraine. The bodies of local self-government are entrusted with a number of powers, for the quality of which they are responsible, such as: ensuring the availability of preschool and secondary education; implementation of state policy at the local level; providing equal conditions for the development of education institutions of all forms of ownership; providing and financing the transportation of teachers and students; development of a network of education institutions. But the critical aspects of the development of education in the conditions of decentralization are: the lack of an effective system for monitoring the quality of education, lack of experience in management of education and activation of teachers in the organization of management of education; change of management structure; minimal impact on the quality of education.

\section{Conclusions}

The article outlines general trends and approaches to educational reform in the conditions of decentralization of Ukraine. The problems of the decentralization process, which began in 2014, were emphasized, namely the regional development and amalgamation of territorial communities, which influenced the dynamics of education institutions that gained more autonomy. It is established that the introduction of decentralization opens the way to changes in creating favorable conditions for the emergence and implementation of intellectual needs of the individual. It is proved that the main task of the government in education in the conditions of decentralization is to coordinate the actions of government agencies, education institutions and the public in order to meet the personal needs of citizens and government demands for intellectual and professional enrichment. It is established that decentralization for higher education institutions should be considered as a means of forming managerial relations in the industry and joint responsibility for the management of the educational process.

Statistical data on the dynamic pattern in the total number of education institutions are studied, in particular, the dynamics of education institutions subordinated to the Ministry of Education and Science of Ukraine in terms of educational levels are presented. The reasons for the decrease in the total number of secondary and vocational education institutions are identified. The degree of financing of the education sector from the consolidated budget of Ukraine by levels of education is considered.

It is determined that the education sector in Ukraine is in transition, and an important component of this process is the correct choice of the vector of movement, taking into account the interests of all stakeholders. The experience of the United Kingdom and the European Union (Denmark, Spain, Poland, Romania, Finland, France) on improving the quality of educational services by strengthening the motivation of teachers using a differentiated payment system is studied and proposed to introduce into the Ukrainian education system.

The possibility of introducing the process of educational / school clustering, which can be a strategy for pooling limited resources and improving access to resources, is considered. 


\section{References:}

Pro mistseve samovriaduvannia v Ukraini: Zakon Ukrainy vid 21.05.1997 № 280/97-VR / Verkhovna Rada Ukrainy [On local self-government in Ukraine: Law of Ukraine No. 280/97-BP dated May 21, 1997 / The Verkhovna Rada of Ukraine]. URL: https://zakon.rada.gov.ua/laws/show/280/97-\%D0\%B2\%D1\%80 (accessed 16 February 2020).

Ministerstvo osvity i nauky Ukrainy. Nova ukrainska shkola. Kontseptualni zasady reformuvannia serednoi osvity [Ministry of Education and Science of Ukraine. Website. The New Ukrainian School. Conceptual principles of secondary education reform]. URL: https://mon.gov.ua/storage/app/media/zagalna\%20serednya/ nova-ukrainskashkola-compressed.pdf (accessed 19 February 2020).

Osvita v Ukraini: Bazovi Indykatory. Pidhotovleno Derzhavnoiu naukovoiu ustanovoiu «Instytut osvitnoi analityky» [Education in Ukraine: Basic Indicators. Prepared by the State Scientific Institution "Institute of Educational Analytics"]. URL: https://mon.gov.ua/storage/app/media/nova-ukrainska-shkola/1serpkonfinformatsiyniy-byuleten.pdf (accessed 16 February 2020).

Expenditure on education as \% of total government expenditure (all sectors): The UNESCO Institute for Statistics. URL: http:// data.uis.unesco.org/Index.aspx?queryid=183 (accessed 21 February 2020).

Seitosmanov, A., Fasolia, O., \& Markhlievski, V. (2019). Starsha profilna shkola: kroky do stanovlennia. Metodychni rekomendatsii [Senior profile school: steps to formation. Guidelines]. Kyiv. (in Ukrainian)

Meleshko, V. V. (2018). Problemy upravlinnia opornymy zakladamy zahalnoi serednoi osvity v umovakh detsentralizatsii [Problems of management of basic general secondary education institutions in the conditions of decentralization]. Ukrainskyi pedahohichnyi zhurnal, no. 2, pp. 27-33.

Tupychak, L. L. (2017). Osoblyvosti detsentralizatsii upravlinnia osvitnoiu systemoiu yak shliakh do modernizatsii vyshchoi osvity v Ukraini [Features of decentralization of education system management as a way to modernization of higher education in Ukraine]. Efektyvnist derzhavnoho upravlinnia, vol. 4, pp. 56-62.

Semeniuk, Yu., \& Kolisnichenko, N. (2019). Vyznachennia ta osnovni poniattia detsentralizatsii osvity [Definitions and basic concepts of decentralization of education]. Derzhavne upravlinnia ta mistseve samovriaduvannia, vol. 3(42), pp. 111-120.

Danylyshyn, B. M., \& Pylypiv, V. V. (2016). Detsentralizatsiia u krainakh YeS: uroky dlia Ukrainy [Decentralization in the EU countries: lessons for Ukraine]. Rehionalna ekonomika, no. 1, pp. 5-11. URL: http://nbuv.gov.ua/UJRN/ regek_2016_1_3 (accessed 16 February 2020).

Boiko, T. Yu. (2017). Finansuvannia zakladiv osvity na miskomu rivni v umovakh detsentralizatsii vlady v Ukraini [Financing of educational institutions at the city level in the context of decentralization of power in Ukraine]. Naukovyi visnyk Khersonskoho derzhavnoho universytetu. Seriia: Ekonomichni nauky, vol. 27(2), pp. 147-151.

Iurchuk, L. (2009). Tendentsii detsentralizatsii upravlinnia osvitoiu v Ukraini [Trends in decentralization of education management in Ukraine]. Visnyk Natsionalnoi akademii derzhavnoho upravlinnia pry Prezydentovi Ukrainy, vol. 4, pp. 276-283.

Hrynevych, L. (2005). Tendentsii detsentralizatsii upravlinnia bazovoiu osvitoiu v suchasnii Polshchi: Avtoref. dys. kand. ped. nauk [Trends in decentralization of basic education management in modern Poland]. Kyiv. (in Ukrainian)

Shyian, R. (2016). Detsentralizatsiia osvity u Polshchi: dosvid dlia Ukrainy [Decentralization of education in Poland: experience for Ukraine]. Kyiv. URL: https://decentralization.gov.ua/uploads/library/file/112/2016-0216-Poland.pdf (accessed 21 February 2020).

Babichev, A. V. (2017). Zarubizhnyi dosvid iz pytan upravlinnia zminamy v systemi vyshchoi osvity [Foreign experience in managing change in the higher education system]. Theory and Practice of Public Administration, no. 2(57). URL: http:/ / www.kbuapa.kharkov.ua/e-book/tpdu/2017-2/doc/5/03.pdf (accessed 20 March 2020). Krystopchuk, T. Ye. (2016). Osoblyvosti detsentralizatsii upravlinnia osvitoiu: dosvid yevropeiskykh krain [Features of decentralization of education management: the experience of the European countries]. Psykholoho-pedahohichni osnovy humanizatsii navchalno-vykhovnoho protsesu v shkoli ta VNZ, vol. 2, pp. $108-117$. URL: http://nbuv.gov.ua/UJRN/Ppog_2016_2_17 (accessed 19 February 2020). 